\title{
Country of origin effects and new financial actors: Private Equity investment and work and employment practices of French firms
}

9560 words

\begin{abstract}
:
This is a study of the effects of alternative investors on a range of work and employment practices in France, paying specific attention to whether investors are indigenous or not. We use data from a detailed survey of French firms, and set our research in the context of the literature on comparative capitalisms. We find that PE investments from abroad are associated with greater job insecurity, less spending on training, and lower wages, but French PE investments are not. We explore the reasons behind this variation, and the implications for theory and practice.
\end{abstract}

\section{Key words:}

Country of origin effects; Varieties of capitalism; Private equity; HRM strategies; Propensity score matching method. 


\section{Introduction}

The implications of new financial actors for companies and employees is of growing concern in the field of management and employment relations, including interest from an international perspective (Gospel \& Pendleton 2014). In a recent article published in this journal, Appelbaum et al. (2013) carried out four case studies for analysing the effect of private equity funding on work and employment relations. Their results suggest that these new financial actors "are not particularly embedded in, or constrained by, national business systems" (p.515).

In this article, we focus on French companies where a financial firm (alternative investors, most commonly Private Equity [PE]) holds a majority stake, and accord particular attention to whether the firm is indigenous or not. There is a growing body of literature that suggests PE will have significant and far reaching effects on the work and employment practices of target organizations; and there is much controversy as to whether such buyouts prejudice employees (see, for example, Appelbaum \& Batt 2014; Bacon et al. 2010; Bacon et al. 2012; Chambost et al. 2008; Clark 2013; Goergen et al. 2014). However, much of the literature has tended to focus on the case of liberal market economies, on overall employment effects, and on indigenous private equity players. By comparing the effects of French and foreign PE investment in French companies on temporary employment, compensation and training, this study seeks to contribute to the emerging literature on cross national PE investments, and the effect of PE on work and employment relations. It brings to bear new evidence from France, supplementing an emerging body of literature on private equity in continental Europe (c.f. Bacon et al. 2012; Boselie \& Koene 2010).

The Varieties of Capitalism literature (Hall \& Soskice 2001; Lane \& Wood 2012) argues that, in general, the Liberal Market Economies (LMEs) are associated with a primary emphasis on shareholder value. In LMEs job protection is lower and unions weaker. In more Coordinated 
Markets (CMEs), this is mediated through stronger stakeholder rights. France has been categorized in numerous different ways, from a coordinated market economy (CME), through a CME that is liberalizing, to state directed capitalism (Hall \& Soskice 2001; Schmidt 2000). A recent study by Witt et al. (2017) reveals that, in terms of a range of regulator and macroeconomic features, France is closer to the Mediterranean and East European EU member states than either an LME or a CME; such economies are characterized by weaker institutional coupling and more room for innovation. Nevertheless, a feature of the country is that employment protection and union rights are relatively strong. The case of France is of particular interest given the history of the higher levels of coordination found there than in Liberal Market Economies (LMEs), a distinct body of corporate law, and the widespread assumption that the French model is in flux (Culpepper 2005) and, hence, particularly vulnerable to pressures from abroad. France is also the second largest investment market for private equity in Europe ${ }^{1}$.

Although there is an extensive literature on country of origin and domicile effects in the case of firms crossing national boundaries, it has tended to focus on differences between the contextual circumstances of firm headquarters versus the country of domicile, rather than the country of origin of investors (Brewster et al. 2008; Edwards et al. 2007; Edwards \& Kuruvilla 2005), and the relative strength of ties between the investor and local actors (Jackson \& Deeg 2008). However, overseas investors may play an important role in initiating and accelerating systemic change (Dore 2008). In addition to country of origin effects, local players are likely to have denser ties to other local actors, which may encourage them to stick to tried and tested national recipes (Jackson \& Deeg 2008; Morgan 2012). Earlier work by Guery et al. (2017) indicated that PE investment from overseas was likely to lead to job cuts, in contrast with French PE investments; we supplement and extend this analysis to cover a wider range of work and employment practices. It is argued that PE investment is characterized by high levels of debt leverage (Cumming et al. 2007), whereas venture capital investment focuses on early stage 
companies which typically lack the assets enabling the same degree of debt leverage, and they are excluded from the main part of our study (c.f. Bottazzi \& Da Rin (2002). However, as an additional robustness check, we also included such firms in our analysis, in order to confirm the distinct consequences of private equity. This study focuses on mature firms, as this has been the scene of most controversy. The analyses are based on a sample of 964 mature workplaces belonging to the 2010-2011 REPONSE dataset. We accord particular attention to the use of temporary employment, to training expenditures, and to the use of restriction, freezing or decrease of compensation levels, all indicators of the relative interdependence of employers and employees (Brewster et al. 2008; Whitley 1999).

\section{Private Equity, Work and Employment}

There is a growing body of research on the consequences of private equity takeovers on firm performance and employment. Cushen \& Thompson (2016) note that alternative investors represent an important vehicle for introducing financialization into non-financial corporations. It has been argued that a PE takeover will result in more effective management, so that even if there are short-term job cuts, employees can look forward with greater confidence to the long term (Wilson et al. 2012). Looking at evidence from 3200 target firms, Davis et al. (2014) found that modest initial job losses were followed by a tendency to more radical upsizing and downsizing than that encountered in the period leading up to the takeover. Wilson et al. (2012) argued that both prior to and after the onset of the financial crisis that began in 2008, PE owned firms outperformed firms not subject to a takeover in terms of job creation potential. Wright et al. (2009) conclude that the bulk of research evidence suggests that in the long-term initial job losses following PE takeovers were compensated for by later hiring once necessary adjustments had been performed. Harris et al. (2005) found that management buy-outs (MBOs) are associated with a shift to less labour intensive production, outsourcing, and the shift of resources towards the most productive areas of activity. Wright et al. (2000) argue that PE 
takeovers accord managers more room to adopt 'entrepreneurial mindsets', which could include forging new accommodations with employees and introducing policies aimed at enhancing commitment.

However, a large component of the mainstream employment relations literature is much more sceptical. It has been suggested that PE takeovers rashly liquidate accumulated assets, discount the value of the capabilities of existing staff, saddle the firm with excess debt, lead to large scale job losses, and endanger the firm's continued existence (see, for example, Appelbaum et al. 2013; Clark 2013). Clark (2009a) argues that PE is fundamentally disruptive to established employment relations through, inter alia, eroding the principle of managerial discretion. Based on four redistribution-level case studies in the UK, Appelbaum et al. (2013) found that PE takeovers were associated with breaches of trust and breaches of implicit contracts: in other words, they eroded the basis of employer-employee interdependence. Contrary to what is held by agency theory, they argue that PE takeovers are not 'welfare neutral', having a more radical approach to shareholder value that further erodes the position of other stakeholders (e.g. Heyes et al. 2012). This means that PE may not only undermine the interdependence of employees and the firm, but also change the extent of delegation to employees (Clark 2007, 2009b). Rather than following a defined template, PE is associated with open-ended transformation of both relations with managers and employment relations generally (Clark 2013). Goergen et al. (2014) found that those investors were associated with greater job shedding, reduced productivity and poorer overall organizational performance.

Most of the existing work on PE does not look at country of origin effects, and assumes that PE will have similar effects irrespective of national context (Appelbaum et al. 2013). Indeed, Bacon et al. (2012) found that rather than national origin, a key determinant of PE effects on HRM was envisaged investment time scale: longer term investment horizons being associated with a greater propensity to introduce HPWPs. Other work on country of origin effects and PE 
primarily concentrates on financial and strategic, rather than work and employment, issues (Bruining \& Wright 2002; Engel \& Stiebale 2014; Meuleman \& Wright 2011). Bedu and Montalban (2013) found that countries with low levels of employment protection were particularly attractive to leverage buy-out orientated PE, suggesting that the business model depended on the ability to readily shed labour. However, in France, recent work indicates that the effects of PE on overall employment were different between French and overseas PE: the effects of French PE on employment were no different to any other French investor, whilst job losses were greater in the case of foreign PE (Guery et al., 2017). We add to this work through exploring the effects of private equity on the relative propensity to make use of temporary labour, to restrict, freeze or decrease compensation levels, and to invest in training.

\section{Institutions, Country of Origin and Domicile}

As the literature on comparative capitalisms (Jackson \& Deeg 2008; Thelen 2014) alerts us, whilst there are dominant forces in the global capitalist ecosystem, these continue to be mediated or reformed through embedded institutional arrangements at regional, national, and supra-national levels (Jessop 2012); firms will tailor their strategies and practices to reap the advantages of local complementarities (e.g. the Varieties of Capitalism approach of Hall \& Soskice 2001; Hancke et al. 2007). More recently, it has been argued that firms (or, indeed, investors) that cross national boundaries are at best only partially embedded within individual institutional regimes: firms will seek to reconcile the benefits of fitting in with local production regimes with the need for internal organizational coherence and the desire to gain the maximum benefits from potential global mobility (Morgan 2012). Whilst the French national context, for example, has many features that are distinct from other institutional regimes, it has been argued that market arrangements are mediated and coordinated through state interventions (Hall \& Soskice 2001; Hancke et al. 2007). Hence, foreign investors may have to temper their agendas 
when entering France, in line with national corporate law and/ or in order to be able to gain some of the specific benefits that accrue from the local regulatory environment.

\section{Private Equity, Work and Employment practices, and country of origin effects: hypotheses}

\section{Divergences in PE industries}

The French PE industry is different from the Anglo-Saxon PE industries, and these divergences might suggest that their influences on the management of the companies funded by PE are different (Bruton et al. 2010). For example, in the UK and in the USA, PE and venture capital firms as a rule are independent institutions, and their main sources of finance include pension funds, insurance companies and other institutional investors (Kaplan et al. 2007). Such PE firms exist of course in France, but others tend to be subsidiaries of banks and other financial institutions (so-called captives) (Mayer et al., 2005). Others are also linked to governmental agencies. These approaches are less common in France than the European average (around $13.5 \%$ of the total fundraising vs. $38 \%$, EVCA 2014), but significant compared to the UK private equity industry for example, where such fundraising is almost non-existent $(1.6 \%$ of the total fundraising, EVCA 2014). These investors' objectives could be broader than just finance. Bpifrance, the main public investment group with the French state as shareholder, introduces itself as a socially responsible investor in its doctrine of intervention (Bpifrance 2013), taking into account the impact of funded companies on their stakeholders, including in terms of territorial employment and development.

Syndication is also a point of divergence. Some case studies, focused on venture capital (Dubocage \& Galindo 2008), or encompassing venture capital and PE (Stevenot 2007), underline the importance of syndication in the French context. As French PE partnerships are generally smaller than American or British ones, PE investments frequently require a syndicate 
of investors. Consequently, the same pool of investors in PE frequently participate in deals involving each other. The consequence is reputational effects. PE firms aspire to be active longterm players in the industry, which depends on their reputational capital, a precious resource in the competitive PE industry which is beset by considerable information asymmetries between PEs and their investors, as well as between PE firms and backed companies (Nahata 2010). A good reputation is therefore critical for PE firms because it helps in developing useful working relationships with entrepreneurs, lawyers, investment bankers, auditors, and others who provide useful services to portfolio companies (Sahlman 1990). A good reputation is also critical in the relationship between PE firms and in the capacity for a PE of being part of further syndications, Wright and Lockett (2003) showing that non-legal sanctions in syndications, such as reputational damage, are important for ensuring cooperation. Given that a majority of PE deals in France involve the formation of PE syndicates, one can suppose that reputational effects in the PE industry are very strong. Furthermore, and maybe due to syndication, the venture capital and PE monitoring of investments is weaker in France than in countries like the UK (Sapienza et al., 1996). For all these reasons, French PE is probably less likely to creature pressure for reducing costs and increasing labour flexibility as part of value extraction.

\section{Private Equity and Temporary Employment}

For employers, particularly in countries where employment law is extensive, temporary employment provides a way of mitigating the effects of job protection legislation and opens up the possibility of adjusting numbers rapidly to meet changing demand. For employees, by contrast, this kind of temporary employment is very much a 'second-best' form of employment with its built-in precariousness. Short-term and temporary employment has become increasingly prevalent in France, and fixed term work may constitute up to $80 \%$ of new hires (OECD 2014). However, as with any change in dominant forms of practice, the use of temporary work may be accelerated by 'norm entrepreneurs' (Dore 2008), who may not only 
seek to increase the portion of temporary labour through the natural ebb and flow of people, but take more aggressive measures to alter the existing composition of the workforce, testing the limits of regulation. It may be that pressure from PE investors from LMEs to facilitate anticipated downsizing will lead to firms increasing the proportion of temporary and fixed term employment more rapidly than their French counterparts. This provides a more nuanced contextualisation for the first hypothesis. Hence,

H1i: The presence of temporary workers is significantly higher in foreign PE backed firms than in French firms with no PE involvement.

H1ii: The presence of temporary workers in French PE backed firms is indistinguishable from French firms with no PE involvement.

\section{Compensation}

Apart from moving towards short-term contracts, two other ways that firms can reduce their interdependence with their people is by holding salaries down and cutting staff development and training. There is a body of existing research that suggests that PE is likely to lead to, at least, constraints on compensation levels and perhaps even to cuts in wages (Appelbaum \& Batt 2014; Goergen et al. 2014). Organizational factors (Balkin \& Gomez-Mejia 1987) and environmental factors (Milkovitch \& Newman 2008) influence compensation, not only the level of salaries but also the compensation structure. Werner et al. (2005) show the impact of ownership structure on the pay of all employees. The use of bonuses is a widespread mechanism for maximising shareholder value, in order to make for greater wage flexibility (Jackson et al. 2005; Conway et al. 2008); it shifts a greater proportion of the risks onto the employee (Lazonick \& Mazzzucato 2013). However, if the foreign PE investors are particularly concerned with short term value release, they may press for immediate pay cuts, 
even if they combine them with measures to introduce greater insecurity into reward systems. Hence,

H2i: Restriction, freezing or decrease of compensation levels is more common in foreign PE backed firms than in French firms with no PE involvement.

H2ii: Restriction, freezing or decrease of compensation levels in French PE backed firms is indistinguishable from French firms with no PE involvement.

\section{Training}

Turning to staff development, any kind of training requires the investment of time and resources, including financial resources. Training is the exemplar HRM activity for defining whether a firm is adopting a policy of value enhancement, which would involve improving workforce capabilities (Guery \& Pendleton 2016), or short-termist redistribution, which would involve cutting training costs (Goergen et al. 2012). France is one of the countries where firm involvement in vocational education and training tends to be high. Until recently French law required firms with more than 20 employees to invest at least $1.6 \%$ of the total payroll in employee training. LME firms generally have much less involvement in staff development (Busemeyer \& Trampusch 2012; Goergen et al. 2012). Even if the level of spending on training is quite high in French firms whoever the shareholders are, we can expect that foreign private equity investors tend to reduce training costs to come closer to the LME's training practices and to improve short-termist finances. On the contrary, we do not expect French PE investors to cut training expenses because they are more embedded in the institutional setting. Therefore we anticipate that:

H3i: Reduction in spending on training is more common in foreign PE backed firms than in French firms with no PE involvement. 
Country of Origin and Private Equity

H3ii: Reduction in spending on training in levels in French PE backed firms is indistinguishable from French firms with no PE involvement.

\section{Methodology}

\section{Data and Variables Definitions}

These theoretical hypotheses are tested using the French 2010-2011 REPONSE survey, conducted by DARES (the research department of the Ministère du travail, de l'emploi, de la formation professionnelle et du dialogue social or Ministry of Labour). This is a nationally representative establishment-level survey. The initial sample includes 4,000 establishments with 11 employees or more, excluding the agricultural sector. We excluded public administration, educational social and health sector, the financial sector, companies whose employees are the main shareholders (as in workers' co-operatives) and listed companies, in order to ensure coverage of establishments that could be funded by private equity to develop their activity (Wood \& Wright 2010). In order to be sure that the establishments in our sample are potentially involved with private equity funding but not venture capital funding, we excluded organizations less than five years old and those with less than 50 employees. Finally, we did not keep establishments that belong to foreign companies, because foreign headquarters can influence work and employment practices in their subsidiaries (Almond 2011). This database allows us to compare foreign and French PE backed firms with a control group of companies whose work and employment practices are not influenced by foreign headquarters. This gave us a resultant sample of 964 establishments.

The REPONSE survey asks whether majority ownership is held by a financial company (alternative investor). The alternative investor ecosystem encompasses private equity, venture capital, Sovereign Wealth Funds (SWFs), and hedge funds. Hedge funds invest in a very wide range of asset classes; in seeking high returns, they rarely seek a majority shareholding or 
outright control of a company, but rather take advantages of short term movements in share prices (Coffee \& Palia 2016). Activist hedge funds seek a change in managerial direction, but their influence on quotidian managerial practice is indirect and again, typically as a minority shareholder in listed firms (Coffee \& Palia 2016). Sovereign Wealth Funds are intended to represent an intergenerational governmental savings device for forex windfalls; here the existing literature suggests their impact on work and employment will be limited (Gospel et al. 2014) or, in the case of the Norwegian one, which has an explicitly ethical brief, positive (Wood et al. 2017). Again, in most instances, SWFs hold only a very small minority of shares (Wood et al. 2017). An exception is France, which has its own SWF type fund, the Strategic Investment Fund, whose focus is on co-investment in strategically important firms, (rather than assuming overall control as PE typically does), albeit that, in comparative terms, it represents quite a small player (Todd 2011). Private equity is different to the previous types of alternative investor in that they normally take a majority shareholding and then delist the company (and, hence, constitutes the overwhelming majority of unlisted firms with financial company majority ownership encompassed by REPONSE), and seeks to release value through explicitly imparting a fresh direction in managerial behaviour (Goergen et al. 2014). Again, a focus on unlisted firms eliminates those that are subject to cross shareholding by banks that also provide loans, which is traditionally identified as a feature of CMEs (Hardie et al. 2013). Hence, in this article, for analytical ease, we refer to PE, but recognise that our sample could potentially encompass the relatively small number of instances where another type of alternative investor assumes overall control. Venture capital - which invests in early stage companies - is excluded from this study (we exclude small and young firms, apart from as a robustness check) ${ }^{2}$.

The REPONSE survey is mainly concerned with industrial relations and human resource management practices, but it is also, to our knowledge, one of the very few databases that includes information on the ownership status of French companies, both listed and non-listed. 
A question asked of one top manager per establishment allows us to know whether ownership is private equity or other shareholders like family, a non-financial company or others. Another question relates to the nationality of the shareholder: French or foreign. In our sample, 9.23\% of the establishments belong to companies funded by French PE and $8.30 \%$ to companies funded by foreign PE. This variable does not allow us to know the country of origin of foreign PE. However, analysing data included in the CFNEWS database about private equity acquisitions of French companies in 2010 reveals that more than $85 \%$ of the foreign investments come from LMEs (mainly the UK and the USA). We can therefore be confident that 'foreign PE' in the REPONSE survey mainly refers to LME PE firms. Although foreign PEs seem to invest in larger and older targets than French PEs (see Table 1), the results of difference in means tests between the characteristics of firms funded by French PE and firms funded by foreign PE gives a more nuanced picture. Indeed, some differences exist between these two groups, but they are infrequently statistically significant (except mainly for industry). We can therefore be confident that French PE and foreign PE are present in similar kinds of establishments, even if differences in industry could perhaps explain some differences in our outcomes.

A first important variable for our study in order to test $\mathrm{H} 1$ is a proxy for contingent employment, that is to say the presence of temporary workers (see Table 2 for descriptive statistics of the main variables, and differences between non-funded establishments, establishments funded by French PE, and establishments funded by foreign PE). A dummy representing the use of restriction, freezing or decrease of compensation to assist the firm during economic crisis is used for testing $\mathrm{H} 2$. For testing $\mathrm{H} 3$, we focus on the changes in training expenses during the last three years. More precisely, the variable is the presence of a decrease of the training expenses level, relatively to the total payroll. 
As management practices of PE backed firms may be affected by some characteristics of the parent firm (size, multi-unit or not) and of the establishment (age, industry, composition of the workforce), all these factors are controlled by dummy variables (see, for example, Davis et al. 2011). Employment management, training expenses, as well as compensation policies may be influenced by the presence of a trade union (Bennett \& Kaufman 2007). We control therefore for trade union presence in the establishment. Four positions are used for industries (industrial sector; wholesale and retail trade; services; others), six for the parent firm size (50-99 employees; 100-199; 200-499; 500-999; 1000-4999; 5000 and more), and four for the age of the workplace (5-9 years; 10-19; 20-49; 50 and more). 'Mono-unit' and 'union representative in the workplace' are dummies. The 'skills ratio' is also a dummy, with 1 when managers and engineers are the main category of employees, 0 if others. Descriptive statistics for all these variables, for the whole sample and across the different categories of ownership can be found in Table 1. Tetrachoric correlations were computed for all the variables used in our analysis and no significant problems have emerged.

\section{Propensity Score Matching Method}

In order to analyse the impact of foreign and French Private Equity investment on work and employment relations in French firms, we estimate a 'causal treatment effect' (Rubin 1974) of private equity on contingent employment, compensation and training, differentiating between French $\mathrm{PE}$ and foreign $\mathrm{PE}^{3}$. We use a matching method, initially used in medical studies, for assessing the causal effect of a treatment (here, being funded by French PE, or by foreign PE) on the work and employment practices we are concerned with. This method consists of matching a treated entity with a non-treated entity with similar characteristics, in order to compute the average effect of the treatment on the treated. It is easy to find similar entities taking into account two or three characteristics, but much more difficult with more characteristics. Rosenbaum \& Rubin (1983) proposed therefore not to use the characteristics 
themselves for matching entities, but a propensity score, that is to say the probability for an entity to receive the treatment regarding their characteristics. In this article, we test the effect of two 'treatments' (i.e. French PE funding and foreign PE funding). Two probit models are therefore used to estimate: 1) the propensity score of being funded by French PE; 2) the propensity score of being funded by foreign PE. This includes, as the dependent variable the dummy for private equity ownership, and as explanatory variables, the characteristics of the establishment and of the parent firm noted above.

As propensity score matching enables us to adjust the selection bias (i.e. on average, companies funded by PE do not have the same characteristics as non-funded companies), we can compare work and employment practices between establishments that are as similar as possible, except for the fact than one establishment (treatment group) is part of a company funded by French private equity and the other is neither funded by PE nor belongs to a foreign company (control group). The same procedure is then replicated for establishments that are part of a company funded by foreign PE. Propensity score matching has become a popular approach to estimate causal treatment effects in non-experimental causal studies (Caliendo \& Kopeinig 2008). It is used for example when evaluating labour market policies (Heckman et al. 1997) or the effect of unionisation on wages (Eren 2007).

Several methods can be used for matching the establishments of the treated group to similar establishments in the control group. There is no clear evidence about how to choose the matching method and it is therefore sensible to use a number of approaches, even if some authors consider that kernel matching is the more reliable (Frölich 2007). We use therefore a number of them as a robustness check: the classical nearest-neighbour matching and two kernel matching functions (Gaussian kernel and Epanechnikov kernel) ${ }^{4}$. With growing sample size, these methods should become closer to comparing exact matches (Caliendo \& Kopeinig 2008). 
The last step of the methodology consists in comparing the matched establishments with respect to their objectives, their training practices, employment practices and compensation practices, in order to analyse the hypothesized effects of private equity. The ATT (average treatment effect on the treated) is then computed by averaging for each outcome the differences between matched establishments. Bootstrapping (Lechner 2002) is used for testing the statistical significance of effects for kernel matching (Caliendo \& Kopeinig 2008), and the Abadie \& Imbens $(2004,2008)$ method for nearest-neighbour matching.

This procedure is firstly used to estimate the effect of French private equity on the presence of temporary workers, then the effect on compensation practices (individual bonuses, collective bonuses, profit sharing, employee share ownership, and restriction, freezing or decrease of compensation as an approach to facing the economic crises), and the decrease of training expenses. It is afterwards replicated for foreign private equity.

\section{Findings}

\section{Descriptives}

Table 2 describes difference in means tests for French PE funded versus non-funded establishments, then for those funded by foreign PE versus non-funded establishments. In other words, it enables us firstly to compare non-funded to funded establishments, then to see if there are differences between French-funded and foreign-funded establishments.

There are clear and significant differences in training expenses, temporary employment, compensation practices and restrictions between establishments funded by foreign PE and nonfunded establishments, whereas the differences between establishments funded by French PE and non-funded establishments are very weak and not significant. The presence of temporary workers and the decrease of training expenses are even slightly less common in French PE 
backed establishments (respectively $43.8 \%$ and 5.7\%) than in non-funded establishments (44.6\% and 7.3\%). Differences are much more significant with foreign PE funded establishments. In these establishments, there is a stronger pressure to favour the presence of temporary workers $(61.2 \%)$, to decrease training expenses $(19.2 \%)$, and to use restriction, freezing or decrease of compensation as a means of facing economic crises (70\% versus $50.3 \%$ for non-funded establishments).

\section{Causal treatment effect of French and foreign private equity (propensity score matching)}

The results of propensity score matching clearly highlight the influence of foreign PE on temporary employment, compensation and training expenses. Our first hypotheses (H1i and H1ii) are confirmed: Whereas French PE investors do not have any influence on insecure labour, foreign PE favours the use of temporary contracts. All the three matching algorithms clearly lead to convergent significant results at the 5\% level (Table 3).

Our second hypotheses ( $\mathrm{H} 2 \mathrm{i}$ and $\mathrm{H} 2 \mathrm{ii})$ dealt with compensation practices. The results of PSM methods are again clear-cut (Table 4). Establishments funded by French PE investors did not use 'restriction, freezing or decrease of compensation' during economic crisis more than nonfunded establishments. By contrast, foreign PE firms favour their use, reflecting a desire to control or reduce the total payroll. This result is significant at the level of $1 \%$ according to the nearest-neighbour matching method and the two kernel matching methods (Gaussian and Epanechnikov).

Our last hypotheses (H3i and H3ii) are that French PE firms are much less likely to reduce spending on training than foreign PE firms. Our results (Table 5) show that French PE funded establishments are not more likely to reduce training expenses than establishments not funded by PE, whilst foreign PE investment is related to a decrease on spending on training and development. The three PSM methods are convergent with significant results at the level of 5\% 
for the two kernel matching methods, at $10 \%$ with the nearest-neighbour matching method. H3i and H3ii are supported by our results.

\section{Discussion and conclusions}

Our findings provide strong evidence for the country of origin effects in private equity investment. We found that constraints on contingent employment, compensation levels and training expenses differed based on PE investors' country of origin. This suggests there is not a single model of private equity. Even if there are dominant trends in the global capitalist ecosystem, new financial actors continue to face varying constraints according to national contexts and their relative embeddedness.

Foreign PE investors were associated with reduced training expenses, employment and constraints on pay. This supplements the findings of Appelbaum, Clark and others (Clark 2009; Appelbaum et al. 2013), who argue that PE results in the breach of contracts. However, our study reveals that it is PE country of origin that influences the strategy imposed on the target firm, rather than PE per se. French PE investors seem more inclined to 'let managers get on with their job' and/ or support an established national recipe. Explanations of these differences may be that either PE behaviour reflects country of origin effects and/ or that indigenous players have denser and thicker ties to other local actors and, hence, are more inclined to concur with local norms, and, as noted above, temper excessively short-termist behaviour (c.f. Jackson \& Deeg, 2008; Morgan, 2012). Indeed, given that French PE partnerships are generally smaller than American or British ones, syndication is wider used. Consequently, the same pools of French investors in PE frequently participate in deals involving each other. Evangelizing hardline approaches to organized labour and promoting job cuts may play well with some international investors, but are likely to alienate French PE actors with strong ties to the state. Again, many French investors are committed to good relations with stakeholders; even those 
that do not will have to take this seriously if they are not to be shunned by potential syndicate partners. They are therefore implicitly encouraged to avoid hardline approaches of human resource management, which could generate negative effects in terms of poor industrial relations that might make managers' work more difficult and jeopardise the public image of the firm. Those with a poor or diminishing reputation will battle to engage in future syndication (Wright and Lockett 2003; Sahlman 1990). However, this would discount the effects of agency: as Simmel (1980) notes, the choices made by actors reflect both objective choices and subjective reinterpretations thereof (Lane \& Wood 2012). Socio-economic conditions may make it harder to adopt very short termist HRM policies in France, but our research indicates that for determined foreign owners it is not impossible.

Hence, an important question for future research would be whether French PE investors would behave the same way when they invest outside of France. Our findings reveal that foreign (mostly LME) PE is more likely to drive more hard-line approaches to managing people in the businesses it invests in, but indigenous PE is less likely to do so. This underscores the relationship between broader political economy, and the relative embeddedness of different players in the PE ecosystem therein. Corporate governance reflects a wide range of contextual dynamics, and clearly there is need for further qualitative and micro-level work on why indigenous PE would be less likely to be concerned with short term value release and breaching psychological contracts with employees than their foreign counterparts.

Our research does have limitations, mainly those created by the use of the particular data source. Whilst this gives us confidence that our survey is representative and reflects an accurate picture of all but the smallest French businesses, it would have been interesting to have more data on the financial history and situation of each firm. We have compared our discussion with the literature and drawn much of our analysis from the Anglo-Saxon PE industry while the data is from 'foreign' firms per se, albeit in an industry that originated in, and remains dominated by 
players from LMEs. Whilst the vast majority of the foreign PE in France is from LME countries, it would have been preferable to have been able to separate out the small number of non-LME investors.

Propensity score matching enables us to compute 'causal treatment effect' based on crosssectional data. However a limitation of this method is that additional observable or unobservable characteristics could differ between the 'treated' observations and their counterparts in the control group. As a consequence, it is still difficult to establish causality links using cross-sectional data. The use of panel data in future researches might overcome this limitation.

It would also be valuable to compare the effects of changes in work and employment relations policies on long-term organisational performance; in other words, does a shift to more hardline HRM policies leave the firm better or worse off in the longer term? Finally, it is recognized that, as with the alternative investor community at large, PE is, in itself, a diverse ecosystem. A key distinction here is between institutional buyouts (IBOs), where the PE buyer replaces the managerial team and strategy), managerial buy ins (MBIs), where a prospective new managerial team arranges outside PE funding to make a takeover possible, and MBOs (where the existing managerial team secures PE funding to take over the firm) (Wood \& Wright 2010). Existing work would suggest that IBOs and MBIs have significantly worse consequences for employees than MBOs (ibid.; Goergen et al. 2014); a more detailed study comparing these different manifestations of PE in France would provide further insights into country of domicile effects and the relative pull of different institutional domains.

Nevertheless, the results are unequivocal. French private equity investors tend to follow the national recipe and maintain employment, pay and conditions and employee training and development broadly in line with other French companies, presumably with the aim of 
developing the assets and making money from long-term growth and expansion. This may partially be explained by the degree of state support for private equity when it serves national or regional developmental objectives (c.f. Gaspar 2012). In contrast foreign PE investors are associated with the use of more contingent policies, with lower levels of investment in people, presumably with the aim of extracting as much short-term value as possible.

This leaves us with outstanding questions, and an outstanding research agenda: is the influence of indigenous PE similarly comparatively benign in other CMEs? Is French PE similarly benign when it is exported to other countries? Is the influence of LME PE similarly negative in other countries? The answers to these questions remain for further empirical research but may well have significant implications for the investment strategies of governments, particularly in developing nations. At a theoretical level, this would indicate that investor country of origin may have just as strong effects as where a firm is headquartered and/ or confirm that indigenous players are more likely to fit in with national recipes owing to their denser ties with local players. This confirms the relevance of socio-economic approaches to comparative institutional analysis, which place the relative embeddedness of players within specific national contexts at the heart of their analysis (Hall \& Soskice, 2001; Jackson \& Deeg, 2008). It also confirms the distinct nature of French capitalism, and that even if delisting may open opportunities to alter work and employment practices, local players continue to opt for the dominant national recipe (even if the latter may itself be in a process of broader change).

\section{REFERENCES}

Abadie, A and Imbens, G.W. (2008). 'On the failure of the bootstrap for matching estimators'. Econometrica, 766: 1537-1557. 
Abadie, A., Drukker, D., Herr, J.L. and Imbens, G.W. (2004). ,'Implementing matching estimators for average treatment effects in Stata'. Stata Journal, 43: 290-311.

Ahmadjian, C.L. and Robbins, G.E. (2005). 'A clash of capitalisms: Foreign shareholders and corporate restructuring in 1990s Japan'. American Sociological Review, 70(3): 451-471.

Almond, P. (2011). 'Re-visiting 'country of origin' effects on HRM in multinational corporations'. Human Resource Management Journal, 21(3): 258-271

Appelbaum, E. and Batt, R. (2014). Private equity at work: When Wall Street manages Main Street. New York: Russell Sage.

Appelbaum, E., Batt, R. and Clark, I. (2013). 'Implications of financial capitalism for employment relations research: evidence from breach of trust and implicit contracts in private equity buyouts'. British Journal of Industrial Relations, 51(3): 498-518.

Bacon, N., Wright, M., Ball, R. and Meuleman, M. (2013). 'Private equity, HRM, and employment'. Academy of Management Perspectives, 27(1): 7-21.

Bacon, N., Wright, M., Meuleman, M. and Scholes, L. (2012). 'The impact of private equity on management practices in European buy-outs: short-termism, Anglo-Saxon, or host country effects?' Industrial Relations: A Journal of Economy and Society, 51(1): 605-626.

Bacon, N., Wright, M., Scholes, L. and Meuleman, M. (2010). 'Assessing the impact of private equity on industrial relations in Europe'. Human Relations, 63(9): 1343-1370.

Balkin D. B. and Gomez-Mejia L.R. (1987). 'Toward a contingent theory of compensation strategy', Strategic Management Journal, 8(2): 168-182.

Bedu, N., and Montalban, M. (2014). 'Analysing the uneven development of private equity in Europe: legal origins and diversity of capitalism.’ Socio-Economic Review, 12 (1): 33- 70.

Bennett J.T. and Kaufman B.E. (2007). What do unions do? A twenty-year perspective, New Brunswick, Transaction Publishers. 
Boselie, P. and Koene, B. (2010). 'Private equity and human resource management: 'Barbarians at the gate! 'HR's wake-up call?' Human Relations, 63(9): 1297-1319.

Bottazzi, L. and Da Rin, M. (2002). 'Venture capital in Europe and the financing of innovative companies'. Economic policy, 17(34), pp.229-270.

Bpifrance (2013). The Doctrine, www.bpifrance.fr

Brewster, C., Wood, G. and Brookes, M. (2008). 'Similarity, isomorphism or duality? Recent survey evidence on the HRM Policies of MNCs', British Journal of Management, 19(4): 320342.

Bruining, H. and Wright, M. (2002). 'Entrepreneurial orientation in management buyouts and the contribution of venture capital'. Venture Capital: An International Journal of Entrepreneurial Finance. 4(2): 147-168.

Bruton, G. D., Filatotchev, I., Chahine, S. and Wright, M. (2010). 'Governance, ownership structure, and performance of IPO firms: The impact of different types of private equity investors and institutional environments'. Strategic management journal, 31(5): 491-509.

Bryson, A., Dorsett, R. and Purdon S. (2002). The use of propensity score matching in the evaluation of active labour market policies, Working paper, $\mathrm{n}^{\circ} 4$, Policy Studies Institute and National Centre for Social Research.

Busemeyer, M.R. and Trampusch C. (2012). The political economy of collective skill formation. Oxford University Press.

Caliendo M. and Kopeinig S. (2008). 'Some practical guidance for the implementation of propensity score matching', Journal of Economic Surveys, 22(1): 31-72.

Chambost I., Hoarau C., Pons P., Roturier P. and Tarrière E. (2008). Financiarisation des entreprises et dialogue social, Rapport Syndex, IRES.

Clark, I. (2007). 'Private equity and HRM in the British business system'. Human Resource Management Journal, 17(3): 218-226. 
Country of Origin and Private Equity

Clark, I. (2009a). 'Owners and managers disconnecting managerial capitalism? Understanding the private-equity business model'. Work, Employment and Society, 23(4): 775-786.

Clark, I. (2009b). 'The private equity business model and associated strategies for HRM: evidence and implications?' International Journal of Human Resource Management, 20(10): 2030-2048.

Clark, I. (2013). 'Templates for financial control? Management and employees under the private equity business model'. Human Resource Management Journal, 23(2): 144-159.

Coffee Jr, J.C. and Palia, D., (2016). 'The wolf at the door: the impact of hedge fund activism on corporate governance'. Annals of Corporate Governance, 1(1):1-94.

Conway, N., Deakin, S., Konzelmann, S., Petit, H., Reberioux, A., and Wilkinson, F. (2008). 'The influence of stock market listing on human resource management: evidence for France and Britain'. British Journal of Industrial Relations, 46(4): .631-673.

Culpepper, P.D. (2005). 'Institutional change in contemporary capitalism: Coordinated financial systems since 1990'. World Politics, 57(2): 173-199.

Cumming, D., Siegel, D.S. and Wright, M. (2007). 'Private equity, leveraged buyouts and governance'. Journal of Corporate Finance, 13(4): 439-460.

Cushen, J. and Thompson, P. (2016). 'Financialization and value: why labour and the labour process still matter'. Work, Employment \& Society, 30 (2): 352-365.

Davis, S J., Haltiwanger, J.C., Jarmin, R.S., Lerner, J. and Miranda, J. (2011). Private equity and employment. Cambridge, Mass: National Bureau of Economic Research.

Davis, S J., Haltiwanger, J.C., Jarmin, R.S., Lerner, J. and Miranda, J. (2014). Private equity, jobs, and productivity. Chicago Booth Research Paper, 14-16.

Dore, R. (2008). 'Financialization of the global economy', Industrial and Corporate Change, 17(6): 1097-1112. 
Dubocage, E. and Galindo, G. (2008). 'Le rôle des capital-risqueurs dans l'isomorphisme stratégique des" biotechs"'. Finance Contrôle Stratégie, 11(4): 5-30.

Edwards, T., Edwards, P., Ferner, A., Marginson, P., \& Tregaskis, O. (2010). 'Multinational companies and the diffusion of employment practices from outside the country of origin'. Management International Review, 50(5), 613-634.

Edwards, T., \& Kuruvilla, S. (2005). 'International HRM: national business systems, organizational politics and the international division of labour in MNCs'. International Journal of Human Resource Management, 16(1), 1-21.

Engel, D. and Stiebale, J. (2014). 'Private equity, investment and financial constraints: firmlevel evidence for France and the United Kingdom'. Small Business Economics, 431: 197-212. Eren, O. (2007). 'Measuring the union-nonunion wage gap using propensity score matching'. Industrial Relations, 46(4): 766-780.

EVCA (2014). '2013 European Private Equity Activity'. European Private Equity and Venture Capital Association.

Frölich, M. (2007). 'Propensity score matching without conditional independence assumptionwith an application to the gender wage gap in the United Kingdom'. Econometrics Journal, 10(2): 359-407.

Gaspar, J.-M. (2012). 'The performance of french LBO firms: New data and new results', Finance, 33(2): 7-60.

Goergen, M., Brewster, C., Wood, G., and Wilkinson, A. (2012). 'Varieties of capitalism and investments in human capital'. Industrial Relations, 51(2), 501-527.

Goergen, M., O'Sullivan, N. and Wood, G. (2014). 'The employment consequences of private equity acquisitions: the case of institutional buy outs'. European Economic Review, 71: 67-79. 
Gospel, H. and Pendleton, A. (2014). 'Financialization, new investment funds and labour'. In Gospel, H., Pendleton, A. and Vitols, S. (Ed.), Financialization, new investment funds and labour: An international comparison. Oxford: Oxford University Press, pp.1-52.

Guery, L. and Pendleton, A. (2016). 'Do investments in human capital lead to Employee Share Ownership? Evidence from French establishments', Economic and Industrial Democracy, 37(3): 567-591.

Guery, L., Stevenot A., Brewster C. and Wood, G. (2017), 'The Impact of Private Equity on Employment: The Consequences of Fund Country of Origin - New Evidence from France', Industrial Relations, 56(4): 723-750.

Hall, P. and Soskice, D. (2001). 'An Introduction to the Varieties of Capitalism', in Hall, P. and Soskice, D. eds., Varieties of capitalism: The institutional basis of competitive advantage, Oxford: Oxford University Press.

Hancke, B., Rhodes, M. and Thatcher, M. (2007). 'Introduction'. In Hancke, B., Rhodes, M. and Thatcher, M. (Ed.), Beyond varieties of capitalism: Conflict, contradiction, and complementarities in the European economy. Oxford: Oxford University Press.

Hansmann, H. (1996). The Ownership of Enterprise. Cambridge, MA: Belknap Press.

Hardie, I., Howarth, D., Maxfield, S. and Verdun, A., (2013). 'Banks and the false dichotomy in the comparative political economy of finance'. World Politics, 65(04):.691-728.

Harris, R., Siegel, D. S. and Wright, M. (2005). 'Assessing the impact of management buyouts on economic efficiency: Plant-level evidence from the United Kingdom'. Review of Economics and Statistics, 87(1): 148-153.

Heckman J., Ichimura H. and Todd P.E. (1997). 'Matching As an Econometric Evaluation Estimator: Evidence from Evaluating a Job Training Program'. The Review of Economic Studies, 64(4): 605-654. 
Heyes, J., Lewis, P. and Clark, I. (2012). 'Varieties of capitalism, neoliberalism and the economic crisis of 2008-?' Industrial Relations Journal, 43(3): 222-241.

Imbens, G. (2004). 'Nonparametric estimation of average treatment effects under exogeneity: A review'. Review of Economics and Statistics, 86(1): 4-29.

Jackson G., Höpner M. and Kurdelbusch, A. (2005). 'Corporate governance and employees in Germany: changing linkages, complementarities, and tensions'. In H. Gospel and A. Pendleton (eds.), Corporate Governance and labour management: an international comparison. Oxford: Oxford University Press. Pp. 84-121.

Jackson, G. and Deeg, R. (2008). 'Comparing capitalisms: understanding institutional diversity and its implications for international business'. Journal of International Business Studies, 39(4), 540-561.

Jessop, B. (2012). 'Rethinking the diversity and variability of capitalism: On variegated capitalism in the world market'. In C. Lane and G. Wood (Ed.), Institutions, Internal Diversity and Change. London: Routledge.

Kaplan, S., Martel, F. and Stromberg, P. (2007). 'How do legal differences and learning affect financial contracts?' Journal of Financial Intermediation, 16(3): 273-311.

Lane, C. and Wood, G. (2012), Capitalism diversity and diversity within capitalism, New York, Routledge.

Lazonick, W. and Mazzucato, M., (2013). 'The risk-reward nexus in the innovation-inequality relationship: who takes the risks? Who gets the rewards?' Industrial and Corporate Change, 22(4), 1093-1128

Lechner, M. (2002), 'Some practical issues in the evaluation of heterogeneous labour market programmes by matching methods'. Journal of the Royal Statistical Society, 165(1): 59-82.

Mayer, C., Schoors, K. and Yafeh, Y. (2005). 'Sources of funds and investment strategies of venture capital funds: evidence from Germany, Israel, Japan and the UK', Journal of Corporate 
Country of Origin and Private Equity

Finance, 11: 586-608.

Meuleman, M. and Wright, M. (2011). 'Cross-border private equity syndication: Institutional context and learning'. Journal of Business Venturing, 26(1), 35-48.

Milkovitch G.T. and Newman J.M. (2008). Compensation. $9^{\text {th }}$ ed., McGraw-Hill.

Morgan, G. (2012). 'International business, multinationals and national business systems'. In Wood, G. and Demirbag, M. (Ed.), Handbook of institutional approaches to international business. Cheltenham: Edward Elgar.

Nahata, R. (2010). 'Reputation in financial intermediation. Evidence from Venture Capital'. In Cumming, D., Venture Capital, Investment strategies, structures, and policies, Wiley, 320-345. OECD. (2014). "Non-regular employment, job security and the labour market divide", OECD Employment Outlook, Chapter 4, 141-210. Paris: OECD.

Rosenbaum, P. and Rubin D.B (1983). 'The central role of the propensity score in observational studies for causal effects'. Biometrika 70(1): 41-55.

Rubin D.B. (1974). 'Estimating causal effects of treatments in randomised and non-randomised studies'. Journal of Educational Psychology, 66(5): 688-701.

Sahlman, W. A. (1990). 'The structure and governance of venture capital organizations'. Journal of Financial Economics, 27: 473-521.

Sapienza, H.J., Manigart, S. and Vermeir, W. (1996). 'Venture capitalist governance and value added in four countries'. Journal of Business Venturing, 11: 439-469.

Simmel, G. (1980). Essays on Interpretation in Social Science. Manchester: Manchester University Press. Smith, J. and Todd, P. (2005). 'Does matching overcome LaLonde's critique of nonexperimental estimators?' Journal of Econometrics, 1251(2): 305-353.

Stévenot, A. (2007). 'Capital-investissement en syndication: les enjeux en termes de gouvernance disciplinaire et cognitive à partir d'une étude de cas multi-sites'. Finance Contrôle Stratégie, 10(4): 141-178. 
Thelen, K. (2014). Varieties of liberalization and the new politics of social solidarity. Cambridge: Cambridge University Press.

Todd, S. (2011). 'France: Internalising Investment'. Investments and Pensions Europe (May). Available at: https://www.ipe.com/france-internalising-investment/40364.fullarticle

Werner S., Tosi, H. and Gomez-Meija, L.R. (2005). 'Organizational governance and employee pay: how ownership structure affects the firm's compensation strategy'. Strategic Management Journal, 26(4): 377-384.

Whitley, R. (1999). Divergent capitalisms. Oxford: Oxford University Press.

Wilson, N., Wright, M., Siegel, D. S. and Scholes, L. (2012). 'Private equity portfolio company performance during the global recession'. Journal of Corporate Finance, 18(1): 193-205.

Witt, M., De Castro, L., Amaeshi, K., Mahroun, S., Bohle, D. and Saez, L. (2017). Mapping the Business System of 61 Major Economies. INSEAD Working Paper 2017/07. Available at: https://www.researchgate.net/publication/306380404

Wood G. and Wright M. (2010). 'Private equity and human resource management: An emerging agenda'. Human Relations, 63(9): 1279-1296.

Wood, G., Goergen, M., O’Sullivan, N. and Baric, M. (2017). 'The Norwegian government pension fund-global and the implications of its activities for stakeholders'. In Cumming, D., Wood, G., Filatotchev, I. and Reinecke, J. The Oxford Handbook of Sovereign Wealth Funds. Oxford: Oxford University Press.

Wright, M. and Lockett, A. (2003). 'The structure and management of alliances: syndication in the venture capital industry'. Journal of Management Studies, 40(8): 2073-2102.

Wright, M., Gilligan, J. and Amess, K. (2009). 'The economic impact of private equity: what we know and what we would like to know'. Venture Capital, 11(1): 1-21. 
Country of Origin and Private Equity

Wright, M., Hoskisson, R.E., Busenitz, L.W. and Dial, J. (2000). 'Entrepreneurial growth through privatization: the upside of management buyouts', Academy of Management Review, 25(3): 591-601. 


\section{APPENDIX}

Table 1. Descriptive statistics of establishments characteristics

\begin{tabular}{|c|c|c|c|c|c|}
\hline & $\begin{array}{c}\text { Global } \\
\text { sample } \\
\text { Freq. }\end{array}$ & $\begin{array}{c}\text { Non } \\
\text { funded } \\
\text { establishm } \\
\text { ents } \\
\text { Freq. }\end{array}$ & $\begin{array}{c}\text { French PE } \\
\text { backed } \\
\text { establish } \\
\text { ments } \\
\text { Freq. }\end{array}$ & $\begin{array}{c}\text { Foreign } \\
\text { PE backed } \\
\text { establishm } \\
\text { ents } \\
\text { Freq. }\end{array}$ & $\begin{array}{l}\text { Difference } \\
\text { in means } \\
\text { between } \\
\text { French } \\
\text { and } \\
\text { foreign PE } \\
\text { backed } \\
\text { establishm } \\
\text { ents (t- } \\
\text { stat) }\end{array}$ \\
\hline \multicolumn{6}{|l|}{ Industry } \\
\hline Industrial sector & 0.321 & 0.324 & 0.202 & 0.425 & $-3.208 * * *$ \\
\hline $\begin{array}{l}\text { Wholesale and retail } \\
\text { trade }\end{array}$ & 0.390 & 0.405 & 0.382 & 0.250 & $2.689 * * *$ \\
\hline Services & 0.221 & 0.198 & 0.348 & 0.312 & 0.491 \\
\hline Others & 0.068 & 0.073 & 0.068 & 0.013 & $-2.309 * *$ \\
\hline \multicolumn{6}{|l|}{ Parent firm size } \\
\hline 50 - 99 employees & 0.197 & 0.221 & 0.114 & 0.051 & 1.465 \\
\hline 100 - 199 employees & 0.197 & 0.214 & 0.126 & 0.115 & 0.215 \\
\hline 200 - 499 employees & 0.196 & 0.192 & 0.218 & 0.217 & 0.006 \\
\hline 500 - 999 employees & 0.141 & 0.138 & 0.149 & 0.153 & -0.078 \\
\hline $\begin{array}{l}1000-4999 \\
\text { employees }\end{array}$ & 0.151 & 0.127 & 0.264 & 0.269 & -0.070 \\
\hline 5000 and more & 0.114 & 0.105 & 0.126 & 0.192 & -1.157 \\
\hline \multicolumn{6}{|l|}{ Age of the establishment } \\
\hline 5 to 9 years & 0.094 & 0.089 & 0.147 & 0.088 & 1.172 \\
\hline 10 to 19 years & 0.213 & 0.197 & 0.340 & 0.227 & 1.614 \\
\hline 20 to 49 & 0.437 & 0.444 & 0.363 & 0.443 & -1.042 \\
\hline 50 and more & 0.254 & 0.268 & 0.147 & 0.240 & -1.522 \\
\hline Mono-unit & 0.370 & 0.384 & 0.370 & 0.225 & $2.075 * *$ \\
\hline Skills ratio & 0.081 & 0.062 & 0.213 & 0.125 & 1.524 \\
\hline $\begin{array}{l}\text { Union representative in } \\
\text { the establishment }\end{array}$ & 0.579 & 0.553 & 0.651 & 0.762 & -1.578 \\
\hline
\end{tabular}

$*$ if $\mathrm{p}<0.10 ; * *$ if $\mathrm{p}<0.05 ; * * *$ if $\mathrm{p}<0.01$ 
Table 2. Univariate difference in means tests

\begin{tabular}{|l|l|l|l|l|l|}
\cline { 3 - 6 } \multicolumn{2}{c|}{} & \multicolumn{2}{|l|}{$\begin{array}{l}\text { Difference in Means } \\
\text { Tests between non } \\
\text { funded establishments } \\
\text { and establishments } \\
\text { funded by French PE }\end{array}$} & $\begin{array}{l}\text { Difference in Means } \\
\text { Tests between non } \\
\text { funded establishments } \\
\text { and establishments } \\
\text { funded by foreign PE }\end{array}$ \\
\hline & $\begin{array}{l}\text { Non } \\
\text { funded }\end{array}$ & $\begin{array}{l}\text { Funded by } \\
\text { French PE }\end{array}$ & $\begin{array}{l}\text { t-stat : } \\
\text { equal } \\
\text { means }\end{array}$ & $\begin{array}{l}\text { Funded by } \\
\text { foreign PE }\end{array}$ & $\begin{array}{l}\text { t-stat : } \\
\text { equal } \\
\text { means }\end{array}$ \\
\hline $\begin{array}{l}\text { Presence of temporary } \\
\text { workers }\end{array}$ & 0.446 & 0.438 & 0.157 & 0.612 & $-2.839 * * *$ \\
\hline $\begin{array}{l}\text { Restriction, freezing or } \\
\text { decrease of } \\
\text { compensation during } \\
\text { the last 3 years }\end{array}$ & 0.503 & 0.511 & -0.146 & 0.700 & $-3.777 * * *$ \\
\hline $\begin{array}{l}\text { Decrease of training } \\
\text { expenses }\end{array}$ & 0.073 & 0.057 & 0.535 & 0.192 & $-3.644 * * *$ \\
\hline
\end{tabular}

$*$ if $\mathrm{p}<0.10 ; * *$ if $\mathrm{p}<0.05 ; * * *$ if $\mathrm{p}<0.01$

Table 3. Propensity score matching - effect of French PE and foreign PE on contingent employment

\begin{tabular}{|c|l|l|l|l|l|l|}
\hline & \multicolumn{3}{|c|}{ Effect of French PE } & \multicolumn{3}{c|}{ Effect of foreign PE } \\
\hline & Effect & SE & OS & Effect & SE & OS \\
\hline Presence of temporary workers & & & & & & \\
\hline Nearest-neighbour matching & -0.113 & 0.072 & 1 & $0.166^{* *}$ & 0.065 & 0 \\
\hline Kernel matching (normal/Gaussian) & 0.011 & 0.053 & 1 & $0.145^{* *}$ & 0.059 & 0 \\
\hline Kernel matching (Epanechnikov) & 0.020 & 0.057 & 1 & $0.134^{* *}$ & 0.058 & 0 \\
\hline
\end{tabular}

$*$ if $\mathrm{p}<0.10 ; * *$ if $\mathrm{p}<0.05 ; * * *$ if $\mathrm{p}<0.01$

Notes: Standard errors for kernel matching algorithms (normal/Gaussian and Epanechnikov) are based on 200 bootstrap replications. Standard errors for nearest-neighbour algorithms are based on the method proposed by Abadie and al. (2004).

OS (off support) indicates the number of treated individuals discarded because of missing 
Table 4. Propensity score matching - effect of French PE and foreign PE on compensation

\begin{tabular}{|c|l|l|l|l|l|l|}
\hline & \multicolumn{3}{|c|}{ Effect of French PE } & \multicolumn{3}{c|}{ Effect of foreign PE } \\
\hline & Effect & SE & OS & Effect & SE & OS \\
\hline $\begin{array}{l}\text { Restriction, freezing or decrease of } \\
\text { compensation during the last 3 years }\end{array}$ & & & & & & \\
\hline Nearest-neighbour matching & -0.079 & 0.082 & 1 & $0.225^{* * *}$ & 0.065 & 0 \\
\hline Kernel matching (normal/Gaussian) & -0.034 & 0.070 & 1 & $0.193^{* * *}$ & 0.057 & 0 \\
\hline Kernel matching (Epanechnikov) & -0.051 & 0.066 & 1 & $0.179 * * *$ & 0.058 & 0 \\
\hline
\end{tabular}

$*$ if $\mathrm{p}<0.10 ; * *$ if $\mathrm{p}<0.05 ; * * *$ if $\mathrm{p}<0.01$

Notes: Standard errors for kernel matching algorithms (normal/Gaussian and Epanechnikov) are based on 200 bootstrap replications. Standard errors for nearest-neighbour algorithms are based on the method proposed by Abadie and al. (2004).

OS (off support) indicates the number of treated individuals discarded because of missing

Table 5. Propensity score matching - effect of French PE and foreign PE on training

\begin{tabular}{|c|c|c|c|l|l|l|}
\hline & \multicolumn{3}{|c|}{ Effect of French PE } & \multicolumn{3}{c|}{ Effect of foreign PE } \\
\hline & Effect & SE & OS & Effect & SE & OS \\
\hline Decrease of training expenses & & & & & & \\
\hline Nearest-neighbour matching & -0.038 & 0.043 & 1 & $0.081^{*}$ & 0.061 & 0 \\
\hline Kernel matching (normal/Gaussian) & -0.035 & 0.029 & 1 & $0.115^{* *}$ & 0.047 & 0 \\
\hline Kernel matching (Epanechnikov) & -0.038 & 0.034 & 1 & $0.109^{* *}$ & 0.049 & 0 \\
\hline
\end{tabular}

$*$ if $\mathrm{p}<0.10 ; * *$ if $\mathrm{p}<0.05 ; * * *$ if $\mathrm{p}<0.01$

Notes: Standard errors for kernel matching algorithms (normal/Gaussian and Epanechnikov) are based on 200 bootstrap replications. Standard errors for nearest-neighbour algorithms are based on the method proposed by Abadie and al. (2004).

OS (off support) indicates the number of treated individuals discarded because of missing

Table 6. Private Equity and Work and Employment Relations, Probit regression, reporting marginal effects

\begin{tabular}{llll}
\hline & $\begin{array}{l}\text { Model 1 } \\
\text { Presence of } \\
\text { temporary } \\
\text { workers }\end{array}$ & $\begin{array}{l}\text { Model 2 } \\
\text { Restriction, } \\
\text { freezing or } \\
\text { decrease of } \\
\text { compensation }\end{array}$ & $\begin{array}{l}\text { Model 3 } \\
\text { Decrease of } \\
\text { training } \\
\text { expenses }\end{array}$ \\
\hline $\begin{array}{l}\text { PE funding } \\
\text { None }\end{array}$ & Ref. & Ref. & Ref. \\
French PE & -.002 & -.018 & -.020 \\
Foreign PE & $(.061)$ & $(.060)$ & $(.026)$ \\
Industry & $.150^{* *}$ & $.187^{* * *}$ & $.093^{* * *}$ \\
Industrial sector & $(.065)$ & $(.058)$ & $(.043)$ \\
Wholesale and retail trade & Ref. & Ref. & Ref. \\
& $-.405^{* * *}$ & $-.136^{* *}$ & -.026 \\
& $(.057)$ & $(.065)$ & $(.031)$
\end{tabular}




\begin{tabular}{|c|c|c|c|}
\hline Services & $\begin{array}{l}-.460 * * * \\
(.046)\end{array}$ & $\begin{array}{l}-.092 \\
(.068)\end{array}$ & $\begin{array}{l}-.0102 \\
(.032)\end{array}$ \\
\hline Others & $\begin{array}{l}-.120 * \\
(.067)\end{array}$ & $\begin{array}{l}-.029 \\
(.064)\end{array}$ & $\begin{array}{l}.011 \\
(.033)\end{array}$ \\
\hline \multicolumn{4}{|l|}{ Parent firm size } \\
\hline 50 - 99 employees & Ref. & Ref. & Ref. \\
\hline 100 - 199 employees & $\begin{array}{l}.016 \\
(.056)\end{array}$ & $\begin{array}{l}-.016 \\
(.054)\end{array}$ & $\begin{array}{l}-.008 \\
(.027)\end{array}$ \\
\hline 200 - 499 employees & $\begin{array}{l}.064 \\
(.059)\end{array}$ & $\begin{array}{l}-.027 \\
(.056)\end{array}$ & $\begin{array}{l}.008 \\
.031)\end{array}$ \\
\hline 500 - 999 employees & $\begin{array}{l}.200 * * * \\
(.063)^{* * *}\end{array}$ & $\begin{array}{l}-.047 \\
(.063)\end{array}$ & $\begin{array}{l}-.008 \\
(.032)\end{array}$ \\
\hline 1000 - 4999 employees & $\begin{array}{l}.152 \\
(.067)\end{array}$ & $\begin{array}{l}-.048 \\
(.065)\end{array}$ & $\begin{array}{l}.052 \\
(.043)\end{array}$ \\
\hline 5000 and more & $\begin{array}{l}.012 \\
(.078)\end{array}$ & $\begin{array}{l}-.149 * * \\
(.070)\end{array}$ & $\begin{array}{l}.019 \\
(.043)\end{array}$ \\
\hline \multicolumn{4}{|l|}{ Age of the establishment } \\
\hline Less than 10 years & Ref. & Ref. & Ref. \\
\hline 10 to 19 years & $\begin{array}{l}.075 \\
(.068)\end{array}$ & $\begin{array}{l}.013 \\
(.064)\end{array}$ & $\begin{array}{l}.050 \\
(.046)\end{array}$ \\
\hline 20 to 49 & $\begin{array}{l}-.057 \\
(.063)\end{array}$ & $\begin{array}{l}.012 \\
(.059)\end{array}$ & $\begin{array}{l}.000 \\
(.034)\end{array}$ \\
\hline 50 and more & $\begin{array}{l}.017 \\
(.068)\end{array}$ & $\begin{array}{l}.126 * * \\
(.062)\end{array}$ & $\begin{array}{l}.057 \\
(.044)\end{array}$ \\
\hline Mono-unit & $\begin{array}{l}.056 \\
(.041)\end{array}$ & $\begin{array}{l}-.086^{* *} \\
(.039)\end{array}$ & $\begin{array}{l}.001 \\
(.027)\end{array}$ \\
\hline Skills ratio & $\begin{array}{l}.043 \\
(.072)\end{array}$ & $\begin{array}{l}.184 * * * \\
(.061)\end{array}$ & $\begin{array}{l}.036 \\
(.040)\end{array}$ \\
\hline Union representative & $\begin{array}{l}.197 * * * \\
(.037)\end{array}$ & $\begin{array}{l}.121 * * * \\
(.037)\end{array}$ & $\begin{array}{l}.010 \\
(.019)\end{array}$ \\
\hline Observations & 944 & 944 & 944 \\
\hline Log likelihood & -547.645 & -620.663 & -247.968 \\
\hline Pseudo $\mathrm{R}^{2}$ & 0.158 & 0.050 & 0.057 \\
\hline Prob>chi2 & 0.000 & 0.000 & 0.017 \\
\hline
\end{tabular}




\footnotetext{
${ }^{1}$ The French PE market is the second largest in Europe after the UK, with about $€ 31.12$ billion funds invested between 2009 and 2013 in 2939 companies (vs. $€ 47.64$ billion and 2351 companies for the UK) (EVCA - Essential Work 2014-2019; Private equity's contribution to building European businesses).

${ }^{2}$ We then explored what would happen when we included younger firms and those less than five years old. Suprisingly, the results were broadly similar, even though debt leverage would be much less significant in such instances (given less assets that could be used as collateral). Although Venture Capital is often seen as having more benign effects on firms (Botozzi \& Da Rin 2002), this did not appear to be the case. This could reflect both the great variability of expertise in the Venture Capital industry, and an ultimate concern with value release within limited time horizons. Full results of this additional analysis are available from the authors.

${ }^{3}$ In a first step we used probit models to test the link between French PE and all our dependant variables (the same for foreign PE). As probit models don't identify causal links, propensity score matching method was preferred (for a comparison between these two methods, see Bryson et al., 2002). Results with probit models (in Appendix, Table 6) and results with propensity score matching are very consistent.

${ }^{4}$ See Caliendo \& Kopeinig (2008), Heckman et al. (1997), Imbens (2004), Smith \& Todd (2005) for overviews of matching methods.
} 